\title{
25 Years of The Geneva Association
}

\author{
by Dieter Farny*
}

As the Geneva Association is now celebrating its 25th anniversary, this is an ideal time for us to draw up an interim balance sheet of the work accomplished and to draw up a program of the tasks to be tackled in the future.

When the Geneva Association was established 25 years ago, its founders wanted more than anything else to call into being an international association devoted to study and research the economics of the common European market in insurance which was already looming on the horizon at that time. They were also somewhat concerned that the European insurance business might be subjected to a high degree of state regulation and for that reason there was a special interest in market economy solutions.

Since those days, the single market for insurance in the European Union has become a reality and, in many countries, the industry has been deregulated. There can be no doubt that the efforts, conferences and debates promoted by the Geneva Association played a considerable part in the development of this European market.

Over the years, the Geneva Association has broadened its scope to cover a much wider range of issues. It now addresses theoretical and practical questions of insurance and risk management generally from a world-wide rather than a purely European perspective. The results of its contributions to the field are published in two highly respected series of publications, which are rated among the most widely read insurance journals in the world. Though the theory of risk management and insurance has now come to occupy the foreground, this has been achieved without losing sight of practical questions of immediate importance. The horizon of the working area of the Association has consequently been greatly expanded.

One obvious change that has come about is that the original and rather cumbersome name - the International Association for the Study of Insurance Economics - has generally been replaced by "Geneva Association".

\footnotetext{
* Director, Institut für Versicherungswissenschaft an der Universität zu Köln, Germany.
} 
Over the 25 years of its existence, the Geneva Association has had many distinguished presidents but Orio Giarini has always remained at the helm as general secretary. The development of the Geneva Association clearly bears the impress of this eminent group of outstanding personalities.

On behalf of the German-speaking profession of theoreticians and practitioners of applied insurance and risk management, I would like to congratulate the Geneva Association on its silver anniversary and to wish it every success in the future. 